\title{
The Comparative Effects of L1 Equivalent versus Contextualized Vocabulary Instruction: EFL Learners' Vocabulary Retention in Focus
}

\author{
Hamed Barjesteh \\ Department of English Language and Literature, \\ Ayatollah Amoli Branch, Islamic Azad University, Amol, Iran \\ Salimeh Alinia \\ Department of English Language and Literature, \\ Ayatollah Amoli Branch, Islamic Azad University, Amol, Iran
}

email: ha_bar77@yahoo.com

\begin{abstract}
This study set out to compare the efficacy of first language (L1) equivalent versus contextualized vocabulary instruction on the vocabulary retention of EFL learners. In this study, forty-five English as foreign language (EFL) learners were divided into three groups, i.e., two experimental and one control group. The experimental groups used first language (L1) equivalent and contextualized vocabulary instruction. The first experimental group received Persian translation of the predetermine word, and the second experimental group received 60 sentences in which they were asked to fill the gap using target words. The words are considered to be the most frequent vocabularies extracted from reading passages of the students' textbooks. Before the intervention, a pre-test of vocabulary was conducted to check the students' knowledge of vocabulary. The data were collected during a period of seven weeks by a post test and a delayed test. The findings revealed that using L1 equivalents could not significantly improve EFL learners' vocabulary retention; however, incorporating contextualized vocabulary instruction promote EFL learners' vocabulary retention. The findings may help EFL teachers and material developers note that vocabulary learning does not happen in isolation. This study suggests that EFL students should take the advantage of contextualized vocabulary instruction for retention of new words.
\end{abstract}

Keywords: Vocabulary, First Language, Contextualized Vocabulary Learning, Vocabulary Retention

\section{INTRODUCTION}

The role of English as an international language is considerable due to its essential purpose as a common language to communicate in the current time its assumed functions such as social, economic, cultural and educational over the world. Ginsburg and McCoy (1981) believe that English is an important language to learn, but this doesn't necessarily mean it is a simple language to master. People meet many challenges when learning English and if learners are aware of the hindrance, they may find more opportunity to master it. Reviewing L2 professional literature (Alroe, \& Reinders, 2015; Nation, 2002; Paribakht, \& Wesche, 1997; Prince, 1996) reveals that a well-balanced language course should follow various strands: meaning-focused input, meaning-focused output, fluency development, and language-focused instruction. A number of authors (Ellis, 1990; Jiang, 2002; Long, 1998; Paribakht \& Wesche, 
1997) postulate that the inclusion of a language focused-instruction strand is not a reaction to communicative approach. They maintain that for most L2 learners, language-focused vocabulary instruction is a cornerstone for a language course. They need to learn vocabulary for both receptive and productive skills. Mezynski (1983) note that it is difficult for learners to comprehend a text containing many unfamiliar words. She further acknowledges the need to examine the process of vocabulary acquisition and its relation to learning from texts.

Allen (1983) postulates that lexical problems break down communication. Nation (1990) believes that the role of vocabulary in language learning especially among four basic skills is important. Accordingly, Nord (1997) justifies two reasons for the importance of vocabulary learning: firstly, vocabulary is a challenging and crucial component of language learning in the EFL context because memorizing and using a lot of words, expressions, and idioms can be problematic for them. The second reason is that vocabulary has a prime role for giving meaning to the sentences and is responsible for communicative purposes. Rodriguez and Sadoski (2000) postulate theoretical and practical justification for vocabulary learning. At the theoretical level, finding how students learn vocabulary can pave the ground for language acquisition. At the operational level, vocabulary is important in mastering a language acquisition.

Learning a recurring theme and L2 professional literature reveal little attention paid on vocabulary acquisition. Wilkins (1972) postulate that "linguists have had remarkably little to say about vocabulary and one can find very few studies which could be of any practical interest for language teachers" (p. 109). Different practitioners and L2 professional researchers in the field (Hummel, 2010; Mizumoto, \& Kansai, 2009; Nation, 2002; Paribakht, \& Wesche, 1997; Shen, 2010) postulate that techniques and strategies in vocabulary instruction are important because learning vocabulary can facilitate the process of language learning strategically and meaningfully. Rodriguez and Sadoski (2000) in their study highlighted what strategies learners use, what they learn about words, how an L2 learners' lexicon is organized, which words are most useful at the onset of language learning, and how students build an understanding of the nexus among the lexicons.

Within the EFL context of Iran, there are two main approaches for teaching vocabularies, namely direct and translation. At high schools, language teachers usually advocate translation approach. More precisely, they provide L1 equivalent for the students in their mother tongue. However, some researchers (Joe, 1995; Nagy and Herman, 1987, Nation, 1990) criticize translation-based instruction. They suggest that the process of acquiring words encompasses inferring words from context. This can facilitate the process of acquisition despite a large number of words students encounter in reading different texts. It should be clarified that students in EFL context of Iran are evaluated either to complete the sentences using given words or using their own information. Their vocabulary knowledge is tested on how to incorporate such knowledge in the context with no attention to their language proficiency level. The problem is that whether providing L1 equivalent or direct teaching can pave the ground for a better vocabulary learning remained unsolved to date. In fact, numerous studies have addressed such issue, but most findings conclude the advantage of direct to indirect and vice a versa. To add the knowledge of existing literature, this study attempts to investigate the possible effects of conditional vocabulary learning on the vocabulary retention of Iranian EFL students based on exploring L1 equivalent versus contextualized vocabulary learning (CVL). This study can be significant due to the fact that learners can find and select a more appropriate way to learn vocabulary. To comply with the objective, the present study intends to find answers to the following research questions:

\section{Research Questions}

1. Does incorporating L1 equivalents promote EFL learners' vocabulary retention? 
2. Does contextualized vocabulary instruction improve EFL learners' vocabulary retention?

3. Is there any significant differential effect between using L1 and contextualized vocabulary learning among EFL learners' vocabulary retention?

\section{REVIEW OF LITERATURE}

In the late 1980s, research in the area of explicit and implicit learning turned to be hot topics in L2 professional literature. In fact, explicit (direct, often de-contextualized) and implicit (indirect, often contextualized) have been discussed in L2 professional literature (Nation, 1990; Ellis, 1994). Ellis (1994) distinguishes main points on explicit-implicit vocabulary learning. He concludes that words cannot be acquired without some noticing and learners are active processors who should utilize strategies in order to derive meaning of a word. Nation (1990) states that explicit vocabulary learning necessitates "a conscious effort to learn vocabulary either in context or in isolation" (p.178). However, he gave a detail account of implicit vocabulary learning as learning new lexis from the neighboring

context during reading or listening.

Different studies have been carried out about the role of different vocabulary learning strategies in EFL contexts (Alroe \& Reinders, 2015; Shangarfam, Ghorbani, Safarpoor \& Maha, 2013; Hayati \& Shahriyari, 2010). In a study conducted with Thai learners of English, Alroe and Reinders (2015) conclude that learning vocabulary with translation was not superior to CVL. Similarly, Qian (1996) concludes that CVL does not always lead to superior retention. Nation (1982) postulates that "...in the initial stages of learning of a new word, a translation will be more meaningful, because it will have many more associations for the learner than will a known synonym in the foreign language" (p.21). Nation (1990) further concludes that learners' mother tongue translation on L2 learning reinforces vocabulary learning due to cognitive connection. Likewise, Harley (1995) supports the idea that learners' mother tongue paves the ground for the learning a new lexical item. He posits that "reference to the LI provides useful support for L2 vocabulary learning" (p. 11). Unlike this study, Shangarfam, Ghorbani, Safarpoor and Maha, (2013) investigate the comparative effects of lexical translation and lexical inferencing techniques on female intermediate EFL learners' vocabulary retention. The findings indicated that using inferencing technique in the EFL classroom can significantly improve students' vocabulary retention.

Likewise, Webb (2008) probes the comparative effects of more informative vs. less informative contexts, and word frequency on mastering incidental vocabulary. The study takes the advantage of short contexts with a single target word. The study investigated recall of form, recognition of form, recall of meaning, and recognition of meaning as the aspects of lexical knowledge. The results reveal that the quality of the context can promote students' knowledge of word meaning. These findings appear to be contradictory with those in Pigada and Schmitt (2006) in which word spelling was the least affected by exposures. Barcroft (2004) discusses five principles for effective second language vocabulary instruction with emphasis on lexical input processing: (1) present new words frequently and repeatedly in the input, (2) use meaning-bearing comprehensible input when presenting new words, (3) limit forced output during the early stages of learning new words, (4) limit forced semantic elaboration during the initial stages of learning new words, and (5) progress from less demanding to more demanding vocabulary-related activities. He emphasized the provision of new words in the input and incremental development of word knowledge and drew attentions to how learners must allocate their limited mental resources in order to acquire multiple components of words knowledge including word form, form-meaning mapping, and second language specific usage. From the 
past to the present, one of the hot topics in EFL context of Iran concerns whether using L1 promote better language learning. There is a general consensus that translation can help learners touch up on meaning. A number of studies have been investigated to explore how meaning is reflected in memory. A study conducted by Johnson Laird, Herrmann, and Chaffin (1984) on the semantic aspects highlights the important role of denotation meaning which accounts for how words are stored on the mind of a learner. Carroll (1994) concludes that words are represented in memory through a sense of relations. Prince (1996) advocates learning vocabulary in a context than learning a vocabulary through translation. He addresses that learning words in contexts comprised three stages as what follows: (a) processing the sentence to understand it, (b) using his or her understanding to infer the meaning, (c) associating the meaning to the form of unknown word for future use. Kroll and Stewart (1994) proposed a model of bilingual lexical processing, i.e., the revised hierarchical model. They postulated that that " 11 word forms are directly linked to meaning at the conceptual level, but that fl meaning is accessed via 11 word forms" (p. 401). As suggested by Cameron (2001) learning vocabulary is a cyclical process. A learner needs to encounter the new words repetitively so as to enter lexical items into the long-term memory system (Laufer, 2005).

\section{METHOD}

\section{Participants}

A convenience sampling procedure was used to examine the possible effects of conditional vocabulary learning on the vocabulary retention of EFL learners. The researcher used the availability sampling technique due to a number of reasons such as readiness to be a part of the sample, availability of the target participant at a given time slot. 60 high school students comprising 21 males and 39 females took part in this study. They were all native speakers of Persian who were placed at the pre intermediate level in an English language institute. They had three to four years of experience in learning English language at different language institutes. Their ages ranged from 14 to 23 . In order to select a more homogeneous participants, they were requested to take an Oxford Placement Test (OPT). After administrating the OPT, 45 students were considered to be qualified for this study.

\section{Instruments}

\section{Oxford Placement Test}

To tap participants' level of English language proficiency level, an Oxford Placement Test (OPT) used to homogenize the subject. The test comprised of 60 items with two parts of reading, vocabulary and grammar test. The first part comprised of 40 multiple-choice items in 4 sections. In section one, students should answer 5 grammatical questions about proposition. Section two, students should read a cloze passage and select one option out of three. In section three, students should read two cloze passages and select one out of four options. Section four includes 40 multiple-choice grammatical items. The second part is divided into two sections. For section one, students are required to read two cloze passages and select the correct option. Section two was devoted to vocabulary item in a multiple-choice format. They were asked to answer the test in 30 minutes. The results were classified based on OPT ranking rubric. 


\section{Frequent English words}

Sixty frequent English words were selected from dialogs and reading passages of the interchange series. The selected words were considered as the most frequent by Richards (2011). For each word, a Persian equivalent was provided. Attempts were made to select concrete unknown words among the frequent word list. The words refer to either an action or to an object. Since the researcher had experience in teaching interchange series, it was easy to distinguish the unknown words among the list of words in the glossary.

\section{Vocabulary Pre-, Post and Delayed-Post-Tests}

Three teacher- made tests were constructed using the frequent word list. The tests were in two forms of multiple-choice item and three reading comprehension tests with contextual clues. The former comprised 20 items with one principal equivalent in Persian language. The latter consisted of twenty items in three reading lists with contextual clues. All the teacher-made tests were assessed by three experts in the field to ensure the content validity of the test. After omitting the vague items, the final revisions were piloted in another language institute with the subjects passing their English courses at the same level of language proficiency. The reliability coefficient of the pretest and post-tests were $.83, .74$, and .76 respectively.

\section{Procedure}

To comply with the objectives of the current study, L1 equivalent and contextualized vocabulary instruction were utilized for the purpose of this study. To collect the data, the students were asked to take an OPT which aimed to select homogenized students. Of the whole participants, 45 students who met the criteria were considered as the subject pool in the present study. They were classified into three groups. More precisely, two groups as the experimental group and one group as the control group. The experimental groups used L1 equivalent strategy and contextualize vocabularies. The control group follows the conventional method of vocabulary instruction. A vocabulary pre-test was administered to all groups. Then, the intervention began utilizing different techniques in each group. More specifically, the teacher gave the Persian meaning of the pre-determined words in the first experimental group. To undertake the study, 60 frequent words were extracted from the reading passages of interchange series. The second group was provided a list of 60 sentences in which they were requested to fill the gaps by using targeted words. It took seven weeks to collect the data. After the intervention, a post test of vocabulary was administered. Next, after a period of four-week interval a delayed post-test was administered to track the effect of instruction.

\section{Research Design}

A quasi-experimental research design (QRD) was adopted to investigate the causal impact of an L1 equivalents and contextualized vocabulary instruction on target population. Notably, the QRD aimed to probe whether L1 equivalents and context on vocabulary instruction can foster EFL learners' vocabulary retention. This sTudy adopted QRD due to a number of reasons such as the availability of the target population, the time limit and their willingness to be a part of the sample. Following Creswell's (2012) guidelines for the research design a pretest-posttest research design was chosen to address the objective of the current study. To answer the research questions, the preliminary assumption was met. Next, a one-way ANOVA, and the post hoc Scheffe test were conducted to compare the performance of EFL learners from the relevant groups. 


\section{RESULTS}

In order to seek if using L1 equivalents have any significant effect on EFL learners' vocabulary retention, students' performance from pre to post-test was compared. A Shapiro-Wilk test of normality was first used to check the normality of the data and the results are presented in table 1. As the results indicate, the data of both pre and post-test are normal $(\mathrm{p}>.05)$, thus parametric statistical analysis can be used.

Table 1. Tests of Normality for First Language group

\begin{tabular}{lllllll}
\hline & \multicolumn{3}{l}{ Kolmogorov-Smirnov ${ }^{\mathrm{a}}$} & \multicolumn{3}{l}{ Shapiro-Wilk } \\
\cline { 2 - 7 } & Statistic & Df & Sig. & Statistic & Df & Sig. \\
\hline L1_pre-test & .143 & 15 & $.190^{*}$ & .929 & 11 & .303 \\
\hline L1_post-test & .212 & 15 & .143 & .929 & 11 & .301 \\
\hline
\end{tabular}

Descriptive statistics of L1 equivalent group on both pre and post-tests vocabulary retention are presented in table 2. The following table indicates that the mean scores of the learners before and after using first language equivalent are 16.26 and 16.44, respectively. To check whether the mean difference is statistically significant paired-sample t-test was conducted.

Table 2. Descriptive Statistics of L1 Group in Vocabulary Retention Tests

\begin{tabular}{llllll}
\hline & Mean & N & $\begin{array}{l}\text { Std. } \\
\text { Deviation }\end{array}$ & $\begin{array}{l}\text { Std. Error } \\
\text { Mean }\end{array}$ \\
\hline \multirow{2}{*}{ Pair 1 } & L1pre-test & 16.26 & 15 & 1.66410 & .46154 \\
\cline { 2 - 6 } & L1_post-test & 16.44 & 15 & 1.57301 & .43627 \\
\hline
\end{tabular}

The results of paired-samples t-test of first language learners' performance on vocabulary retention is presented in the Table 3 .

Table 3. Paired Samples t-Test of L1 Group in Pre-test and Post-test

\begin{tabular}{|c|c|c|c|c|c|c|c|c|}
\hline \multicolumn{6}{|c|}{ Paired Differences } & \multirow[t]{5}{*}{$\mathrm{t}$} & \multirow[t]{5}{*}{$\mathrm{df}$} & \multirow{5}{*}{$\begin{array}{l}\text { Sig. } \\
\text { (2-tailed) }\end{array}$} \\
\hline & \multirow{4}{*}{ Mean } & \multirow[t]{4}{*}{ Std. Deviation } & Std. & \multirow{3}{*}{\multicolumn{2}{|c|}{$\begin{array}{l}95 \% \text { Confidence } \\
\text { Interval of the } \\
\text { Difference }\end{array}$}} & & & \\
\hline & & & Error & & & & & \\
\hline & & & \multirow{2}{*}{ Mean } & & & & & \\
\hline & & & & Lower & Upper & & & \\
\hline Pair 1 & -.384 & 2.06 & .572 & -1.63 & .862 & -.67 & 12 & .584 \\
\hline
\end{tabular}

Table 3 indicates that the sig value is greater than .05. Thus, it can be stated that the mean difference from pre to post-test is not significant and first language learners' performance does not improve as a result of vocabulary retention. In other words, using L1 equivalents does not have any significant effect on EFL learners' vocabulary retention. To probe if incorporating CVL has any significant effect on EFL learners' vocabulary retention, learners' performance of contextualized group from pre-test to post were compared. Shapiro-Wilk test of normality was first used to check the normality of the data. Table 4. Indicates that the data are normal $(\mathrm{p}$ $>$.05). Thus, the parametric statistical analysis can be used.

Table 4. Tests of Normality for contextualized Group

\begin{tabular}{cllllll}
\hline & \multicolumn{4}{l}{ Kolmogorov-Smirnov ${ }^{\mathrm{a}}$} & \multicolumn{3}{l}{ Shapiro-Wilk } \\
\cline { 2 - 7 } & Statistic & df & Sig. & Statistic & Df & Sig. \\
\hline Pre-test & .234 & 15 & $.169^{*}$ & .789 & 13 & .413 \\
\hline Post-test & .223 & 15 & .153 & .789 & 13 & .401 \\
\hline
\end{tabular}


Descriptive statistics of the contextualized group on both pre and post-tests vocabulary retention are presented in Table 5.

Table 5. Descriptive Statistics of Contextualized Group in Pre-test and Post-test

\begin{tabular}{cccccl}
\hline & & Mean & N & Std. Deviation & Std. Error Mean \\
\hline \multirow{2}{*}{ Pair 1 } & Pre-test & 16.53 & 15 & 1.290 & .368 \\
\cline { 2 - 6 } & Post-test & 17.330 & 15 & 1.082 & .302 \\
\hline
\end{tabular}

Table 5 indicates that the mean scores of the learners before and after using CVL are 16.53 and 17.33 , respectively. To check whether the mean difference is statistically significant and meaningful, a paired-sample t-test was run. The results of paired-samples t-test of contextualized group's performance on vocabulary retention is presented in the Table 6 .

Table 6. Paired Samples t-Test for the Pre-test and Post-test in Contextualized Group

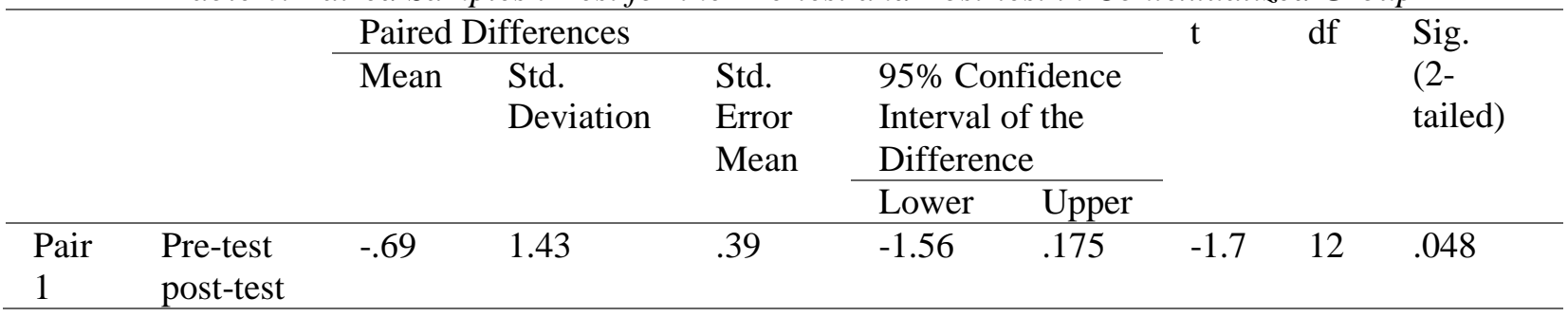

Table 6 indicates that the mean difference from pre to post-test is significant and contextualized group's performance improved as a result of vocabulary retention. This shows that using contextualized vocabulary instruction has a significant effect on students' vocabulary retention. To seek if there is a meaningful differential effect between using L1 and CVL among EFL learners' vocabulary retention, a one-way ANOVA was conducted.

Table 7. Test of Homogeneity of Variances

\begin{tabular}{lccc}
\hline Score & & & \\
\hline Levene's Statistic & df1 & df2 & Sig. \\
\hline .223 & 2 & 36 & .801 \\
\hline
\end{tabular}

Table 7 reveals that the sig. value is greater than $p>.05$. Accordingly, it can be stated that the variances in the scores are the same for each of the three groups. Thus, the test of homogeneity of variance indicates that we can safely run one-way ANOVA. To check the differential effect of using different strategies on vocabulary retention, the data were analyzed using descriptive and inferential statistics. The following Table 8 presents the descriptive statistics of the data in the post-test. As it can be seen, the mean of the three groups in the posttest is different. To see whether the mean difference is statistically significant, the test of Homogeneity of Variances and one-way ANOVA were used.

Table 8. Descriptive Statistics of Three Groups in the Post-test

\begin{tabular}{|c|c|c|c|c|c|c|c|c|c|}
\hline \multirow[t]{2}{*}{ Group } & \multirow[t]{2}{*}{$\mathrm{N}$} & \multirow[t]{2}{*}{ Mean } & \multirow[t]{2}{*}{ SD } & \multirow[t]{2}{*}{$\begin{array}{l}\text { Std. } \\
\text { Error }\end{array}$} & \multicolumn{2}{|c|}{$\begin{array}{l}95 \% \text { Confidence } \\
\text { Interval for Mean }\end{array}$} & \multirow[t]{2}{*}{ Min } & \multirow[t]{2}{*}{ Max } & \multirow[t]{2}{*}{$\mathrm{BCV}$} \\
\hline & & & & & $\begin{array}{l}\text { Lower } \\
\text { Bound }\end{array}$ & $\begin{array}{l}\text { Upper } \\
\text { Bound }\end{array}$ & & & \\
\hline 1 & 15 & 16.2 & 1.0 & .30 & 15.5 & 16.8 & 15 & 18 & \\
\hline 2 & 15 & 16.3 & 1.4 & .40 & 15.5 & 17.2 & 14 & 19 & \\
\hline
\end{tabular}




\begin{tabular}{|c|c|c|c|c|c|c|c|c|c|}
\hline 3 & & 15 & 15. & 1.7 & .49 & 13.9 & 16.0 & 13 & 19 \\
\hline Total & & 45 & 15.8 & 1.5 & .24 & 15.3 & 16.3 & 13 & 19 \\
\hline \multirow[t]{2}{*}{ Model } & $\mathrm{FE}$ & & & 1.4 & .23 & 15.3 & 16.3 & & \\
\hline & $\mathrm{RE}$ & & & & .43 & 13.9 & 17.7 & & .41 \\
\hline
\end{tabular}

Table 8 indicates that the mean and standard deviation for each group are as follows: L1 group $(X=16.23, S D=1.09)$; contextualized group $(X=16.38 ; S D=1.44)$ and control group $(X=$ $15.87 ; S D=1.55)$. In order to find out whether the mean difference of the three groups is statistically significant and meaningful, a one-way ANOVA was run on the scores of the three groups. Table 9 indicates the result of one-way ANOVA on vocabulary retention post-test of the three groups after they receive vocabulary learning instruction.

Table 9. One-way ANOVA for the Post-test of Vocabulary Retention
\begin{tabular}{llllll}
\multicolumn{5}{c}{} \\
\hline Between Groups & Sum of Squares & df & Mean Square & F & Sig. \\
\hline Within Groups & 77.974 & 2 & 7.487 & 3.483 & .041 \\
\hline Total & 92.359 & 36 & 2.150 & & \\
\hline
\end{tabular}

Table 9 reveals that there is a significant difference $\left(F_{(38)}=3.48 ; p<.05\right)$ among the performance of L1, contextualized and control groups in vocabulary retention after the instruction. Therefore, it can be stated that the three groups had meaningful differential effect. To locate the exact differences, the post hoc Scheffe test was conducted. Table 10 presents the Post-hoc Scheffe test for the multiple comparisons of the post test scores.

Table 10. Post-hoc Scheffe Test for Multiple Comparisons in the Post-test

\begin{tabular}{lllllll}
\hline $\begin{array}{l}\text { (I) } \\
\text { Group }\end{array}$ & $\begin{array}{l}\text { G) } \\
\text { Group }\end{array}$ & $\begin{array}{l}\text { Mean } \\
\text { Differenc } \\
\text { e (I-J) }\end{array}$ & $\begin{array}{l}\text { Std. } \\
\text { Error }\end{array}$ & Sig. & \multicolumn{2}{l}{$\begin{array}{l}\text { 95\% Confidence } \\
\text { Interval }\end{array}$} \\
\cline { 3 - 7 } & & & & $\begin{array}{l}\text { Lower } \\
\text { Bound }\end{array}$ & $\begin{array}{l}\text { Upper } \\
\text { Bound }\end{array}$ \\
\hline \multirow{2}{*}{ L1 } & L1 & -.15 & .57 & .96 & -1.6 & 1.31 \\
& Control & 1.2 & .57 & .11 & -.23 & 2.6 \\
\hline \multirow{2}{*}{ Context } & context & .15 & .57 & .96 & -1.3 & 1.6 \\
\cline { 2 - 7 } & Control & 1.3 & .57 & .06 & -.08 & 2.8 \\
\hline \multirow{2}{*}{ Control } & L1 & -1.2 & .57 & .11 & -2.6 & .2 \\
& context & -1.38 & .57 & .06 & -2.8 & .083 \\
\hline
\end{tabular}

Table 10 indicates that there is no significant difference among the three groups in vocabulary retention after receiving different instructions. This shows that there is no significant interaction among L1, context and control groups.

\section{DISCUSSION}

This study is an effort to provide more insights into two types of vocabulary learning conditions, namely L1 equivalent and contextualized vocabulary instruction in EFL learners' retention of the English words. With respect to the findings obtained from data analysis concerning translation and context recall, students' performance did not improve when L1 equivalence were used for EFL Learners' vocabulary retention. However, using contextualized vocabulary instruction significantly improved EFL learners' vocabulary retention. Similarly, 
Saleem Khan (2016), and Khansir \& Tabande (2014) conclude that students' native language plays a beneficial role in learning vocabulary retention. Likewise, Greggio and Gil's (2007) study indicated that learners L1 is effective as a viable learning strategy to both clarify their understanding of lesson content and as a means of participating in class discussion. The findings reveal that students' mother tongue can facilitate the interaction between students and foreign language learning.

With respect to the results obtained from the analysis of the data pertaining to L1 retention, the students could give the meaning better in the classroom context than the other groups when the teacher asked the meaning of those words. The reason may be that Iranian teachers still use Grammar Translation Method in their EFL classroom settings. The finding of the present study is consistent with Karimian and Talebinejad (2013) and Liao (2006) who believed that using L1 can be a useful instrument in language learning but it does not have a significant effect in vocabulary retention. This finding echoes Krashen (1987) who posts that most L2 students tend to choose a low effort strategy like translation than a high effort one such as inferencing.

This finding is against Mehpour (2008) who concluded that word memorization from a list can work better than a sentence making from Iranian learners of English. This finding might be due to the language proficiency level of students. Following Krashen (1987), students with low language proficiency advocate low effort strategy than high effort one. The results also echo past studies (Cook, 2003; Jiang, 2002; Liu, 2009; Schmitt, 2008) that highlighted incorporating students' L1 equivalents in the EFL classroom, more specifically at the initial phase of the learning process when the basic form-meaning linkage has to be formulated.

With respect to the results obtained from the pre-intermediate students in this study, contextualized vocabulary instruction was more effective than using L1 equivalent for students' vocabulary retention. The findings also revealed that students' performance in the contextualized group improved their vocabulary retention. Although providing the synonyms are easier, recalling the new words through contextualizing strategy can facilitate vocabulary retention. This finding is in line with considerable studies (Amirian \& Momeni, 2012; Rashtchi \& Rezvani, 2010) that pointed out practicing words in contexts are more useful than decontextualized contexts. Oxford and Scarcella (1994) also believe that decontextualized learning using students' mother tongue can help students memorize vocabulary. However, they are likely to forget words memorized from lists. This finding echoes Qian (1996) who acknowledge the process of vocabulary acquisition through contextualized instruction. Similarly, the findings are in line with Nation (2002) and Jiang (2002) who advocated meaningfocused learning. The finding also echoes Prince (1996) three main assumptions for learning words. He maintained that learning words in contexts encompass processing the sentence to understand it, utilizing one's understanding to derive the meaning, and associating the meaning to the form of unknown word for the future use, He further posited that learning vocabulary in a context is superior than learning words through translation Learning.

\section{CONCLUSION}

This study was an attempt to probe the effectiveness of learning words in context and learning words via translation. The findings support the advantages of utilizing context in learning vocabulary. This finding does not imply that learning words through translation is ineffective. Using learners' L1 can be useful for the first stage of language learning. It can pave the ground for depicting meaning of a word which reinforce form-meaning connection. Thus, it can help learners retain words as a cognitive hook. Learners can also utilize this technique as a means validating the meaning. It is noteworthy that context-based and definition-based are neither 
the only vocabulary learning techniques nor the best techniques that are available for learning. Introducing and having learners practice by using alternative vocabulary learning strategies can be considered as an effective way of enabling learners to achieve more effective independent vocabulary learning in the future. Other extra activities that also produce improvement in students' vocabulary knowledge include having them work on different types of vocabulary exercises which require students to process the new word at different cognitive levels.

\section{REFERENCES}

Allen. F. A. (1983). Techniques in teaching vocabulary. New York: Oxford University Press.

Alroe, M., \& Reinders, H. (2015). The role of translation in vocabulary acquisition: a replication study. The Eurasian Journal of Applied Linguistics, 1(1), 39-58.

Amirian, S., \& Momeni, S. (2012). Definition-based versus contextualized vocabulary learning. Theory and Practice in Language Studies, 2 (11), 2302-2307.

Barcroft, J. (2004). Second language vocabulary acquisition: A lexical input processing approach. Foreign Language Annals, 37(2), 200-208.

Cameron, L. (2001). Teaching Languages to Young Learners. Cambridge: Cambridge University Press. http://dx.doi.org/10.1017/CBO9780511733109

Carroll, D.W. (1994). Psychology of language. Pacific Grove: California. Brooks/Cole Publishing Company.

Cook, V. J. (2003). Effects of the Second Language on the First. Clevedon: Multilingual Matters.

Ellis, N. (1994). Vocabulary acquisition: the implicit ins and outs of explicit cognitive mediation. In N. C. Ellis (ed). Implicit and Explicit Learning of Languages, 211 - 282.

Ellis, R. (1990). Instructed second language acquisition. London: Blackwell.

Gingsburg, H., \& McCoy, I. (1981). An empirical rationale for foreign language in elementary schools. Modern Language Journal, 65, 36-42.

Greggio, S., \& Gil, G. (2007). Teacher's and learner's use of code-switching in the English as a foreign language classroom: a qualitative study. Linguagem and Ensino,10 (2) 371-393.

Hayati, M., \& Shahriari, A. (2010). The impact of L1 equivalents versus context on vocabulary recall of pre-university EFL students. The Journal of Teaching Language Skills, 2(3), $27-51$.

Harley, B. (1995). Introduction: the lexicon in second language research. In Harley, B. (Ed.), lexical issues in language learning (pp. 1-28). Philadelphia: John Benjamins.

Hummel, K. M. (2010). Translation and short-term L2 vocabulary retention: Hindrance or help? Language Teaching Research, 14(1), 61-74.

Jiang, N. (2002). Form-meaning mapping in vocabulary acquisition in a second language. Studies in Second Language Acquisition, 24(4): 617-637. http:// dx.doi.org/10.1017/ S0272263102004047

Joe, A. (1995). Text-based tasks and incidental vocabulary learning. Second language Research, , 11(2), 149-158.

Johnson Laird, P. N., Herrmann, D. J. \& Chaffin, R. (1984). Only connections: A critique of semantic networks. Psychological Bulletin, 96, 292-315.

Karimian, Z., \& Talebinejad, M. R. (2013). Students' use of translation as a learning strategy in an EFL classroom. Journal of Language Teaching and Research, 4(3). 605-610.

Khansir, A. A., \& Tabande, Y. (2014). The effects of Persian language on vocabulary learning of Iranian EFL students. International Journal of Language Learning and Applied Linguistics World, 6(3), 62-75.

Krashen, S. D. (1987). Principles and practice in second language acquisition. London: Prentice Hall International.

Laufer, B. (2005). Focus on form in second language vocabulary learning. In S.H. Foster-Cohen, M. Garcia-Mayo and J. Cenoz (Eds.), Eurosla yearbook volume 5 (pp. 223-250). Amsterdam: John Benjamins. http://dx.doi. org/10.1075/eurosla.5.11lau

Long, M. (1988). Instructed interlanguage development. In L. M. Beeble (Ed.). Issues in Second Language Development. New York: Newbury House. 
Liu, J. (2009). L1 Use in L2 Vocabulary Learning: Facilitator or Barrier. International Education Studies, 1: 65-69.

Mehrpour, S. (2008). A comparison of the effects of two vocabulary teaching techniques. Asian EFL Journal, 10 (2), 1-20.

Mezynski, K. (1983). Issues concerning the acquisition of knowledge: Effects of vocabulary building on reading comprehension. Review of Educational Research, 53(2), 253-279.

Mizumoto, A. \& Kansai, O. T. (2009). Examining the effectiveness of explicit instruction of vocabulary learning strategies with Japanese EFL university students. Language Teaching Research 13(4) 425-449. doi.org/10.1177/1362168809341511

Nagy, W., \& Herman, P. (1987). Breadth and depth of vocabulary knowledge: Implications for acquisition and instruction. In M. McKeown \& M. Curtis (Eds.), the nature of vocabulary acquisition (pp. 19-35). Hillsdale, NJ: Erlbaum.

Nation, I. S. P. (1983). Testing and teaching vocabulary. Guidelines, 5, 12-25.

Nation, I. S. P. (1990). Teaching and learning vocabulary. Rowley, MA: Newbury House.

Nord, C. (1997). Translating as a purposeful activity. Functionalist approaches explained. Manchester: St. Jerome.

Oxford, R, \& Scarcella, R (1994). Second Language vocabulary learning among adults: State Of the art in vocabulary instruction. System, 22(2), 231-243.

Paribakht, T. S. \& Wesche, M. (1997). Vocabulary enhancement activities and reading for meaning in second language vocabulary acquisition. In Coady, J. \& Huckin, T. (Eds.), Second language vocabulary acquisition, 174-200. New York: Cambridge University Press.

Pigada, M., \& Schmitt, N. (2006). Vocabulary acquisition from extensive reading: A case study. Reading in a Foreign Language, 18, 1-28.

Prince, P. (1996). Second vocabulary learning: The role of context versus translations as a function of proficiency. Modern Language Journal. 80, 478-493.

Qian, D.D. (1996). ESL vocabulary acquisition: Contextualization and de-contextualization. The Canadian Modern Language Review, 53 (1), 120-142.

Rashtchi, M., \& Rezvani, F. (2010). Vocabulary learning strategies: Do they help Iranian EFL learners to overcome vocabulary learning difficulties? Journal of English Studies, 1(1), 65-79.

Richards, J. C. (2011). Interchange series (4 ${ }^{\text {th }}$ edition). Cambridge: CUP.

Richards, J. C. \& Renandya, W. (2002). Methodology in language teaching: an anthology of current practice. New York: Cambridge

Rodriguez, M. \& Sadoski, M. (2000). Effects of rote, context, key word, and context/key word methods on retention of vocabulary in EFL classrooms. Language Learning, 50, 385-412.

Schmitt, N. (2008). Instructed Second Language Vocabulary Learning. Language Teaching Research, 12 (3): 329-363. http://dx.doi. org/10.1177/1362168808089921

Shangarfam, N. Ghorbani, N. Safarpoor E. \& Maha, M. (2013). The comparative impact of lexical translation and lexical inferencing on EFL learners' vocabulary retention. Management Science Letter, 3(12), 2889-2908.

Shen, H. H. (2010). Imagery and verbal coding approaches in Chinese vocabulary instruction. Language Teaching Research, 14(4), 485-499.

Webb, S. (2008). Receptive and productive vocabulary sizes of L2 learners. Studies in Second Language Acquisition, 30, 79-95.

Wilkins, D. (1972). Linguistics in language teaching. Cambridge: CPU. 